\title{
HUNGARIAN TRENDS AND GENDER DIFFERENCES IN THE GLOBAL SMOKING EPIDEMIC ${ }^{1}$
}

\section{András Wéber}

\section{ABSTRACT}

This paper analyzes whether developments in Hungary are in keeping with the trends of the process known as the "global smoking epidemic." To this end, the comparative cases of the USA and Austria are used as a benchmark for reviewing the results concerning tobacco consumption and sex differences in mortality. A comparative analysis has been conducted using prevalence and tobacco-related mortality data in longer-term perspectives. The study analyzes the descriptive statistics of the smoking-attributable premature mortality trends in Hungary between 2000 and 2015 by sex, age, and cause of death, using the updated method of the American Centers for Disease Control and Prevention. The results show that Hungarian men are suffering more destructive consequences of the smoking epidemic than American or Austrian men. Hungarian and Austrian women are half a century behind the peak of the epidemic in the USA, and the harmful effect is also smaller than in the USA. Nevertheless, we can also predict that differences by sex will decrease significantly in the future. Between 2000 and 2015, male smoking-attributable mortality declined in Hungary; meanwhile, among women it increased dramatically. As a consequence, in the over-50 age group, increasing tobacco-related mortality is holding back the improvement in female mortality. The key causes of death attributable to

\footnotetext{
1 Funded by the project entitled "EFOP-3.6.3-VEKOP-16-2017-00007 - Young researchers from talented students Fostering scientific careers in higher education", which is co-financed by the European Union (European Social Fund) within the framework of the Széchenyi Program 2020.
} 
smoking - e.g., bronchitis, emphysema, and COPD, and lung, bronchus, and trachea cancers - are also identified. All this means that, in every age group and for almost all causes of death, the differences by sex declined significantly in the period analyzed. Our results indicate that compared to the United States, the possibly more traditional gender roles characterizing Austrian and Hungarian society, and the related cultural norms, reduced the harm arising from the cigarette epidemic among Central and Eastern European women. However, a strong negative cohort effect can also be identified in the Hungarian female population born between 1945 and 1965, largely due to smoking. This implies that the promotion of a healthy life style among middle-aged and older females could be a major policy target.

Keywords: mortality, healthy-life risk factors, smoking, smoking-attributable mortality, gender differences

\section{András Wéber}

Demographer, Hungarian Central Statistical Office - Population Statistics Section PhD-Candidate, University of Pécs - Doctoral School of Demography and Sociology European Doctoral School of Demography - University of Southern Denmark

E-mail: andras.weber@ksh.hu 


\section{INTRODUCTION}

"Death in old age is inevitable, but death before old age is not." Sir Richard Doll

Richard Doll was the British epidemiologist who - back in 1950 - was among the first scientists to confirm the association between smoking and increased risk of lung cancer (Doll and Hill, 1950). His research contributed to identifying cigarette smoking as the single most important and preventable cause of premature death in developed countries and it is also a major public health concern in many regions of the developing world (Lopez et al., 1994).

Since Doll's ground-breaking findings, more recent research has demonstrated not only that smoking is associated with lung cancer, but also that its deleterious effects are more general, extending to the whole body. Consequently, the addiction has a determining role in the development of not one, but several, chronic diseases that can lead to death, e.g., ischemic heart disease or chronic obstructive pulmonary disease (COPD) (USDHHS, 1989).

Three different approaches are used to measure smoking-attributable mortality in a population. The first takes account only of deaths due to lung cancer, and will therefore always be an underestimate (Kubík et al., 1998; Bray et al., 2004; Tyczynsky et al., 2004). But prolonged cigarette smoking causes deaths that are related to diseases other than lung cancer. For this reason, Peto et al. (1992) developed another indirect method of estimation. They assigned to tobacco a certain proportion of deaths from specific disease categories on the basis of the risk ratios found in longitudinal studies, and then calculated the number of deaths that could be attributed to smoking. The third approach is the official calculation by the American Centers for Disease Control and Prevention (CDC), which was introduced in 1989 (since when it has undergone several updates). This approach utilizes all the data used in the previously mentioned methods, plus the prevalence of smoking² in the population (USDHHS, 1989; 2014; Shultz et al., 1991; Józan and Radnóti, 2002; Vitrai et al., 2012; KSH, 2014; Wéber, 2017).

Peto et al., in their comprehensive periodic report entitled "Mortality from Smoking in Developed Countries 1950-2010," offer a detailed account of the effect of smoking. According to them, in 2005 some 2.7 million men and 1.4 million women in total died between the ages of 35 and 69; of these deaths, 0.7 million and 0.2 million were due to smoking, yielding a proportion of roughly $26 \%$ and $14 \%$, respectively (Peto et al., 2012). In Hungary, the picture is even

\footnotetext{
${ }^{2}$ The proportion (frequency of occurrence) of people with specific diseases, in this case smokers, in the total population.
} 
worse: in 2009, some 31,000 men and 16,000 women aged 35-69 died; of these deaths, 13,000 and 4,600 were attributable to cigarette consumption - 42\% and $29 \%$, respectively. The raw figures show that smoking places a huge burden on developed societies and economies generally. And in this context the Hungarian situation is particularly bad: beyond doubt the smoking epidemic has much deeper roots in Hungarian society.

Since it is possible to quantify smoking-attributable mortality, we can estimate the economic costs. We can split the expenditure due to tobacco consumption into two main parts: on the one hand, there are the "direct costs" - the expense of medical treatment related to smoking-attributable disease (e.g., medicine and patient care) and the extra expenses incurred by the social security system (sick pay, disability pension); on the other hand, the lost lifeyears and the lost productivity of active women and men due to their premature death are usually referred to as "indirect costs." In the case of US citizens, the direct costs of smoking were nearly USD 176 billion in 2012, while the indirect cost was approximately USD 151 billion, based on annual averages for 20052009 (USDHHS, 2014). If the same methodology is applied to Hungary, in 2010 the direct cost was USD 1.3 billion and the indirect cost was more than USD 352 million (Balku and Varsányi, 2016). Looking at these inconceivably large sums and the overwhelmingly negative impact of smoking in Hungary (Vitrai et al., 2012), it may be said that any decision to raise the excise tax on tobacco in order to suppress consumption can be supported scientifically. This is confirmed by the International Agency for Research on Cancer (IARC) in its review of more than 100 econometric studies (quoted in Jha and Peto, 2014). This confirmed that tobacco taxes and consumption are strongly and inversely related. It concluded that a $50 \%$ increase in inflation-adjusted tobacco prices reduces consumption by about 20\% in high-, low- and middle-income countries alike (Jha and Peto, 2014).

The purpose of this paper is, first, to examine the global historical trends and the expected future of the smoking epidemic, reviewing the core literature and theories on tobacco consumption and mortality. The reference country is the USA, which has made greater strides than elsewhere in the developed world. At the same time, because of its proximity and similar cultural and historical background, Austria is also used as a benchmark for Hungary. Secondly, genderspecific models are presented and gender differences are analyzed. The paper demonstrates a longer-term narrowing of the differences between the sexes; this raises a number of important sociological questions, such as the blurring of the boundaries between gender roles in the developed societies of the twentyfirst century. Thirdly, premature smoking-attributable mortality is calculated for 
Hungary (using the official method of the CDC) between 2000 and 2015 and is analyzed in terms of sex, age group, and cause of death. This paints a particularly unfavorable picture for middle-aged Hungarian women; therefore, the final section of the study focuses on their situation and on the explanatory factors, including a social-policy section. Last, but not least, the paper intends to explain more comprehensively Hungary's unfavorable smoking figures, and to contribute in a modest way to a decline in premature smoking-attributable mortality.

\section{DESCRIPTIVE MODEL OF THE CIGARETTE EPIDEMIC}

\section{Basic model}

Well-dressed men sitting around a table, smoking during a meeting; Audrey Hepburn with her emblematic cigarette holder, as a representative of emancipation; passengers puffing on cigarettes on an airplane while chatting these are all everyday images from the 1950s and 1960s.

They reveal a world that had embraced the habit of smoking and in which tobacco control strategies did not yet exist - despite the findings of Doll concerning smoking's negative impact on health (Doll and Hill, 1950). One reason why the mid-century evidence of hazard was ignored (at least initially) is the delay between the widespread adoption of smoking by young adults and the appearance of the main effects on mortality in later life. Because men started smoking before women, the effects among middle-aged men have been apparent for longer in most high-income countries (Jha and Peto, 2014). In this respect, the concept of delay is of particular importance, and is the key element in the theory developed by Lopez et al. in their 1994 article "A descriptive model of the cigarette epidemic in developed countries." Their research was based on nearly a hundred years of observations in countries with the longest histories of widespread cigarette use, and they proposed a four-stage model of cigarette consumption and subsequent mortality among men and women. From their model it is clear that current mortality is most closely related to previous - rather than current - levels of cigarette consumption. They also point out the long delay between the onset of persistent smoking and the corresponding massive increase in the death rate three or four decades later. Thus, current smoking-attributable mortality in the present is most closely related to smoking patterns 30 or more years ago, rather than to current prevalence (Lopez et al., 1994). With regard to smoking-attributable mortality, the death 
rate from lung cancer was used by researchers at that time, and this may have led to the earlier underestimation of deaths due to addiction.

Stage 1 is the beginning of the smoking epidemic in a population. The prevalence of smoking is relatively low among both men and women (and in the case of women, socio-cultural factors discourage smoking). Nicotine addiction then becomes socially acceptable, while strategies for tobacco control remain underdeveloped. Smoking among men rises rapidly, and some (though still relatively few) male deaths are attributable to tobacco.

In Stage 2, the prevalence of smoking among men continues to rise rapidly until it peaks. Smoking prevalence among women typically lags behind that of men by one to two decades, but it also increases rapidly. Tobacco control activities in this phase are generally not well developed.

In Stage 3, male prevalence starts declining. By the end of this stage, there may also be the beginnings of a decline in female prevalence, following a plateau (which may continue for longer than among men). Knowledge about the health hazards of tobacco is generally widespread, and the peak in female prevalence is likely to be considerably lower than that for men. There is a rapid rise in smokingattributable mortality among both sexes. Female deaths due to smoking are still comparatively low, but a sharp rise is to be expected. A comprehensive package of tobacco control laws and regulations may be introduced. Smoking changes from being socially acceptable to socially unacceptable behavior.

In Stage 4, the smoking prevalence of both sexes continues to decline. The rise in male mortality from smoking may be expected to peak early in this period. Conversely, female deaths due to smoking are likely to rise rapidly, as the health effects of smoking earlier in life become more evident. Thereafter, smokingattributable mortality progressively declines for both sexes. Based on scientific evidence, comprehensive controls on smoking become institutionalized.

Furthermore, researchers emphasize that other countries have the benefit of knowing the serious health consequences of smoking, and can undertake effective preventive interventions at earlier stages of the epidemic (Lopez et al., 1994).

\section{Completion of the model}

Almost two decades after Lopez et al. published their model of the cigarette epidemic, Thun et al. (2012) produced further research entitled "Stages of the cigarette epidemic on entering its second century." In this work, they attempted 
to verify, revise, and update the (nearly) 20 -year-old findings. The proportion of all deaths attributed to tobacco was calculated for 41 high- and medium-income countries from 1950 to the most recent year for which data were available (generally 2005-2009). The trends in tobacco-attributed mortality in later middle age were then projected to 2025, based on recent trends in tobaccoattributed mortality in early middle age (Thun et al., 2012).

Three important remarks can be made with respect to the two studies above. First, the lung cancer death rates used formerly were updated using the indirect estimations carried out by Peto et al. (1992). This was a quantitative development: the authors could now eliminate the underestimation of deaths due to addiction in earlier phases of the epidemic (an advance on the methods employed in previous studies). Secondly, the more recent study ignores the qualitative analysis of sociological and social-political factors (unlike the basic model). For instance, neither the spread of smoking across the socio-economic classes (and any variations in those trends) nor the development of tobacco control strategies (such as an increase in the tax on tobacco in order to suppress consumption) is considered (Jha and Peto, 2014). It is possible that this omission is intentional, since it would be hard to explain why, if tobacco control strategies affect the whole population, the gender differences are so pronounced, according to the stage theory. Thirdly, the researchers propose a modification of the original model to allow for the different stages to be separated into male and female epidemics in a particular country. The revised model, like the original, illustrates a delay of many decades between an upsurge in cigarette smoking by young adults and the impact on mortality. It confirms that women who smoke like men will die like men. The authors add that gender-specific differences are influenced by economic, cultural, and political determinants that differ greatly from one population to another. For example, female smoking lagged behind male smoking by only 20-30 years in the USA and the UK, because cultural prohibitions on women smoking largely collapsed during and after World War II (Thun et al., 2012).

According to their results, the prevalence of smoking in the USA has continued to decline among both sexes, although the rate of decrease has slowed and is less than predicted by the original version of the model. Over the past 20 years, the proportional contribution of smoking to all deaths has decreased among men, but has continued to increase (or has plateaued) among women. Projections up to 2025 suggest that in America, male and female smoking prevalence and smoking-attributed mortality will decrease in parallel towards lower - as yet undefined - limits. In developing countries, the model seems generally applicable to men; but it cannot predict whether (or when) women will 
start smoking in larger numbers. Finally, Thun et al. conclude that the four-stage model of the cigarette epidemic still provides a reasonably useful description of the processes in many developed countries. Its relevance to developing countries could be improved by describing the stages of the epidemic separately for men and women (Thun et al., 2012).

In 2004, Bray et al. examined recent trends in lung cancer mortality rates among men and women in each of the then 15 EU countries, comparing crosssectional rates of death among the younger (30-64 years) and older populations (65 or over), and looking at the age, period of death, and birth cohort influences in the younger age group. Their results confirm the findings of the updated basic model, and the age analysis emphasizes the fundamental cohort influence characteristic of smoking. In the background, we find different degrees of health awareness in different generations, as well as the influence of tobacco control strategies. Bray et al. found that among males, a decline in lung cancer mortality is apparent in most countries - at least among younger men; rates among older men either plateaued or also fell. In younger age groups, the decreasing risk of death from lung cancer reflects changes in successive birth cohorts, due to modifications in smoking habits from generation to generation, although the stage of these developments varies greatly from country to country. Among women, recent decades have witnessed an unambiguous surge in lung cancer mortality rates in both the younger and the older female population in almost all EU countries, and there are no clear signs that the epidemic has peaked or soon will peak (Bray et al., 2004).

\section{The situation in Hungary}

Meslé and Vallin (2017) clearly demonstrate a divergence between the developed Western world and the Central Eastern European countries. In the mid-1960s, when the developed Western countries were joining the cardiovascular revolution, the Eastern European socialist systems failed to follow them; furthermore, they suffered from increasing mortality from "man-made," chronic (cardiovascular and cancer) diseases - mainly a result of high alcohol and tobacco consumption. This is called the East-West divergence by the authors (Meslé and Vallin, 2017). It is also known as the "State Socialist Mortality Syndrome," as defined by Carlson and Hoffmann (2011). In his detailed research, Józan (2008) describes the situation as it applied to Hungary. He identified the phenomenon of a "chronic, qualified epidemiological crisis" between 1966 and 1993 in Hungarian 
society, when the frequency of cardiovascular and cancer deaths determined the increasing level of mortality. This was mostly the case among middle-aged men, who experienced a significant decline in life expectancy at this time (the term "qualified" refers to this). As a cause, he identified (among other things) the characteristics of a dictatorial political system: "The resources needed to change lifestyle, the improvement of the physical environment and the introduction of up-to-date and costly medical technology, the Hungarian economy in crisis was unable to realize" (Józan, 2008).

From 1994, some improvement is to be observed in Hungary; as a result, life expectancy at birth is now the highest it has ever been in Hungary (although contemporary society has inherited high mortality due to the cancer and cardiovascular diseases associated with the period of state socialism). In 2014, it was 72.1 years for men and 78.9 years for women - an increase of 7.6 years and 5.1 years, respectively, in the relatively short period since 1993. The change of regime led to the emergence of a market economy and an open society. In Hungary, this was a turning point: life expectancy increased with the emergence of a competitive, open society and - more importantly - health-conscious behavior. The cardiovascular revolution that has occurred (albeit considerably later than in Western countries) has brought a large drop in cardiovascular deaths; but in terms of cancer mortality, the improvement is much smaller (if indeed there is any). In fact, the outbreak of the "chronic, qualified epidemiological crisis" in Hungary coincided with one of the highest levels of smoking prevalence in the US; and as the promotion of health awareness was not among the priorities of the socialist system, the Hungarian population was hit by a smoking epidemic that lasted decades longer than in the United States.

Thanks to accurate and precise data collection (smoking prevalence and tobacco-related mortality) in the relevant literature, it is possible to examine the question more closely and see how the trends in Hungary fit with the trends of the global smoking epidemic.

From 1984 to 2014, a significant drop of $12 \%$ can be observed in the prevalence of smoking among Hungarian males. This decrease over three decades is in line with the trends elsewhere, but the figures at the start of the period were generally higher in Hungary than in the USA or Austria; moreover, the decline was slower. Obviously, this lag is visible in the extremely high proportion of smokingattributable deaths in Hungary: from 1955 to the mid-1990s, there was a steep rise in the trend. In the course of those four decades, tobacco-related mortality leapt from a figure of $9 \%$ to $31 \%$, and that proportion has stagnated since 2000. In 2009, this indicator was roughly 1.5 times greater than in the USA, and double the figure 
for Austria. According to the model of the cigarette epidemic, the Fourth Stage is when the proportion of smoking-attributable deaths starts to decline; but no such trend is detectable in Hungary. Thus Hungary is lagging at least two decades behind the USA - and possibly more than 40 years behind Austria!

Hopefully, the prevalence of smoking among Hungarian women plateaued between the mid-1990s and 2010, and the proportion of deaths has stabilized at around $26-28 \%$. In Austria, the phenomenon looks similar, though the values are lower. The trajectory of female smoking shows a half-century delay compared to the USA, and also the level of the plateau is lower. Compared to Austria, the considerable lag in the decline in female smoking prevalence in Hungary means that any downward movement in the proportion of tobacco-related deaths will also take longer to show up. Thus it may be predicted that female smokingattributable mortality will increase for some decades in both countries, but will not reach the level seen in the US in the 2000s. The Hungarian situation is particularly worrying, given that in 2009 the proportion of tobacco-related mortality was twice as high as in Austria (14\% versus 6.9\%).

Figure 1: Smoking prevalence and the smoking-attributable mortality of the male population in the USA, Hungary, and Austria, 1900-2025

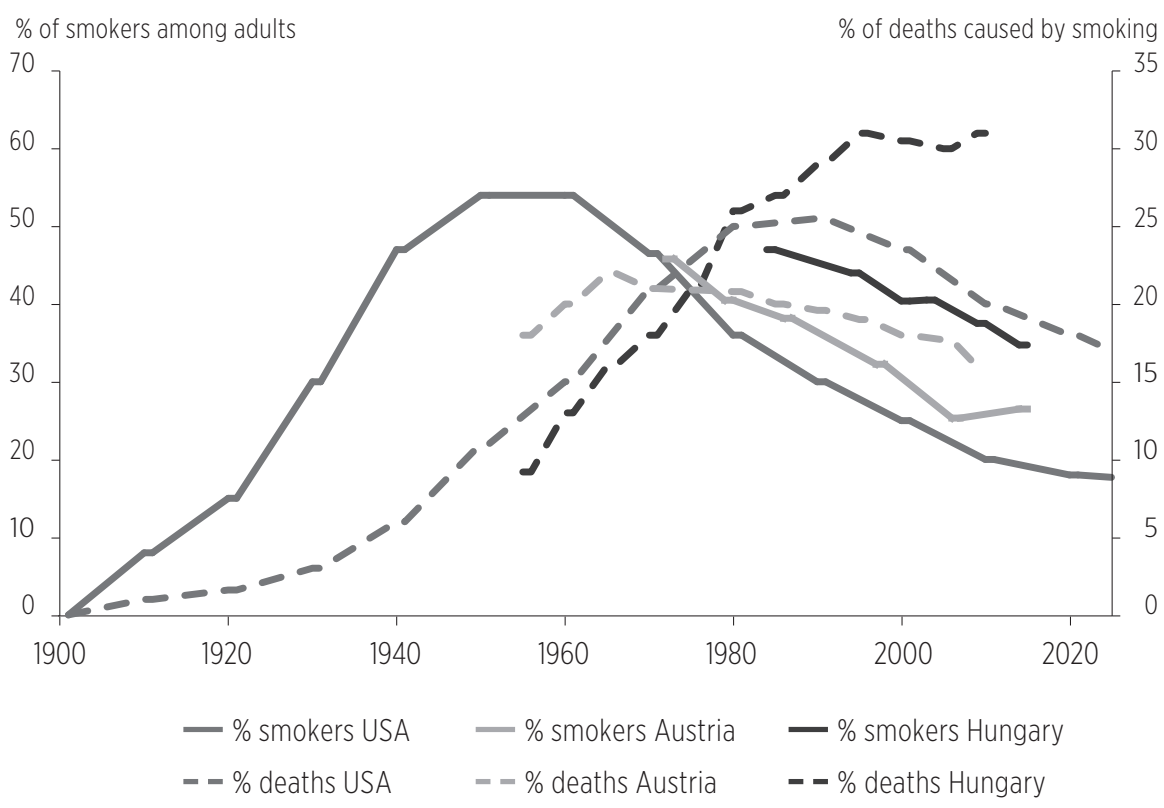

Source: See Appendix I. 
Figure 2: Smoking prevalence and the smoking-attributable mortality of the female population in the USA, Hungary, and Austria, 1900-2025

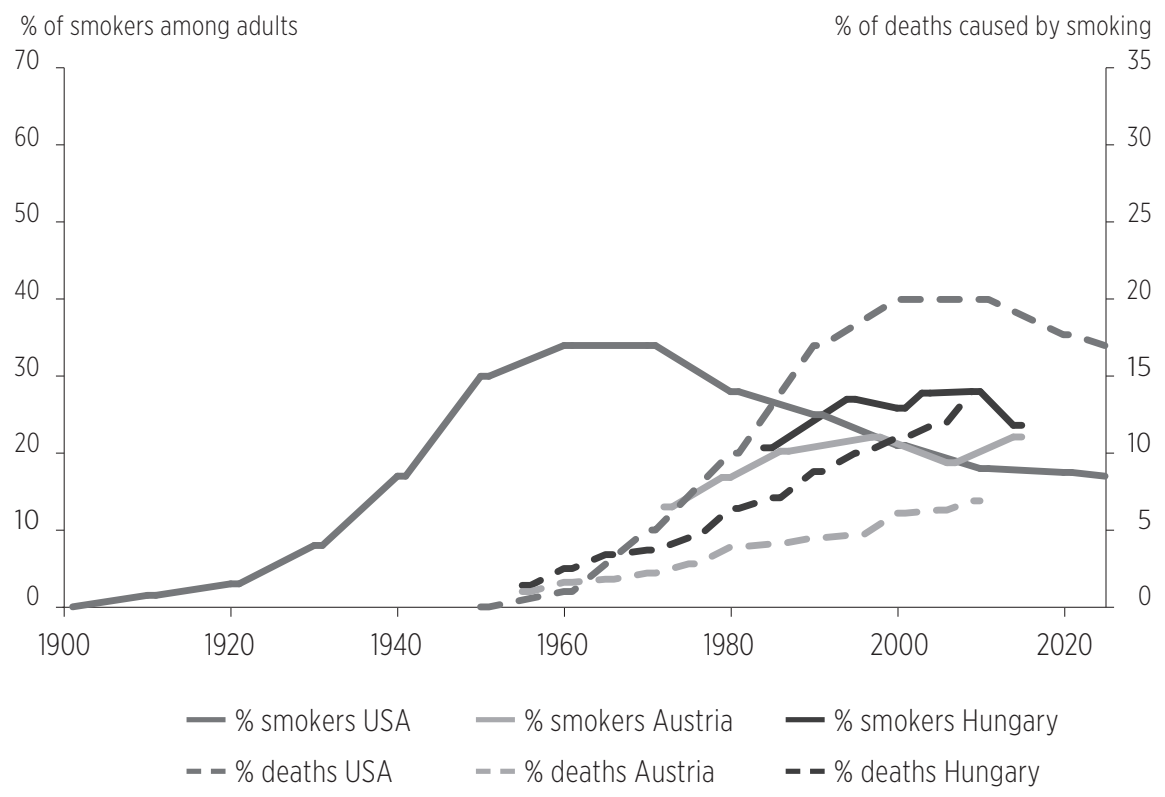

Source: See Appendix I.

International comparative analyses consistently recognize the unfavorable health situation in Hungary due to tobacco consumption and confirm the above findings. Thun et al. (2012) concluded that among men aged 35-69, the proportion of all deaths attributable to smoking has decreased in Hungary; nevertheless, it still remains at a very high level. Among women, smoking prevalence has also decreased in many developed countries, but the proportion of female deaths at age 35-69 attributable to smoking has not yet fallen substantially; in some countries, it has continued to rise rapidly and is currently highest in countries like Hungary. Kubík et al. (1998) examined the development of the lung cancer epidemic in four Central European countries (Austria, the Czech Republic, Hungary, and Slovakia) for the period 1990-2009, taking into account earlier lung cancer mortality trends (1960-1989). They found that over the period from 1985-1989 to 2005-2009, the age-adjusted lung cancer mortality rates for men were predicted to increase in Hungary, and to show little change in Austria. For women, an almost exponential increase in lung cancer mortality rates was to be expected, with the highest rates in Hungary and much lower values in Austria. 
Lung cancer mortality among women is still much lower than among men, but it is increasing rapidly (Kubík et al., 1998). Tyczynski et al. (2004) also analyzed the longer-term trends in lung cancer (between 1960 and 2000) as a cause of death in 10 countries admitted to the EU in 2004. They found that lung cancer was the most frequent cause of cancer death among males in all the countries examined, with the highest proportions in Hungary. The most common pattern in the countries concerned showed a previous increase in mortality (in the 1970s, and in some countries in the 1980s), followed by a decline in the 1990s in this specific cancer as a cause of male deaths. The exception was Hungary, where no decrease in mortality could be observed. The situation was no better among females: the only country that saw a significant acceleration in the rate of increase was Hungary. According to the authors' categorization, it was possible to distinguish three groups of countries with different patterns of female mortality. The first comprised the three Baltic countries, where the level of mortality was relatively low, and the increase in mortality over time was negligible. Four other countries (the Czech Republic, Poland, Slovakia, and Slovenia) formed the second group, with a higher level of mortality and a rather constant increase in the rate of mortality. The third group included just one country - Hungary - the only country where the rate of increase was accelerating; the level of mortality there was approximately double that of any other country. The researchers also tried to shed light on why lung cancer ratios in the older EU Member States were much lower than in the newer EU countries (Tyczynski et al., 2004). On the one hand, this was most probably because the smoking epidemic started later in the newer EU states, and consequently the decline in smoking also came later in most of those countries. On the other hand, the difference was also rooted in the much earlier implementation of tobacco control measures in many of the older EU members.

\section{GENDER DIFFERENCES IN THE EPIDEMIOLOGY OF SMOKING}

\section{Basic theory}

Pampel (2002) examines the details of gender differences in cigarette-smoking mortality in his study, Cigarette Use and the Narrowing Sex Differential in Mortality. The theoretical starting point for the research was the gender-equality theory. Traditionally, higher levels of income, power, and prestige among men have 
coexisted with higher levels of mortality. The gender-equality theory suggests that the move toward social and economic equality between men and women will tend to equalize their mortality (Pampel, 2002). The basis of the thesis is the phenomenon of delay, just as in Lopez et al. (1994), described above. Pampel proposes that if one views the 1960s as the beginning of the most recent period of change in the status and role of women, and recognizes that in terms of the major causes of mortality in modern societies there is a lag of several decades between the adoption of unhealthy behaviors (or the experience of unhealthy living conditions) and death, then the gender-equality thesis accurately predicts the narrowing of the sex differential in the 1980s and 1990s.

However, such a macro descriptive theory as the gender-equality thesis has been widely criticized. On the one hand, according to Trovato and Lalu (1996), the hypothesis is too one-sided, in that it fails to consider the changes in male behaviors and roles that - alongside changes in female behaviors and roles affect the sex differential (Trovato and Lalu, 1996). In this context, we can mention Lopez's argument that males have adapted less well than females to the more comprehensive process of modernization, and that much of the increase in male excess mortality has resulted from the widespread adoption of hazardous life styles by men and the general mismanagement of health (Lopez, 1983). On the other hand, even women with high education, in high-prestige occupations, and enjoying high income maintain a substantial longevity advantage over men, and so higher occupational status does not raise mortality among women (Waldron, 1993; 2000).

Recalling the research of Waldron (1986), that smoking represents a major source of the differences in mortality between men and women (explaining about half of the differential), Pampel (2002) asks: "if high rates of tobacco use by men relative to women largely explain the growth of the sex differential over most of twentieth century, can changes in tobacco use by men and women explain the more recent reversal in the sex differential in mortality?" After examining the trends in cigarette use and lung cancer, he concludes that they can. Behind all this lies the fact that men took up smoking in large numbers earlier than women, and more recently have stopped smoking faster than women (Pampel, 2002).

Pampel's research compares changes in smoking and non-smoking deaths among women relative to men in 21 high-income countries, by examining the mean mortality rates and the logged ratio between 1975 and 1995, taking into account age in two categories: 35-69 and 70+, and using the data reported by Peto (Peto et al., 1992). Based on his analysis, the author identified three groups of countries. In the first, an increase in the advantage enjoyed by women could 
be observed (e.g., Japan, France, Germany, Austria, Greece, and Spain). In the second, there had been little change in the sex differential (e.g., Canada, Finland, Australia, Ireland, Belgium, Switzerland, Portugal, and Italy). Pampel explained this phenomenon as follows: the harm of smoking to women had become serious enough in those countries to counter the improvements made in female mortality among non-smokers. In the third group (e.g., the USA, New Zealand, the UK, the Netherlands, Denmark, Sweden, and Norway), a decline in the female advantage could be detected (Pampel, 2002). The author concluded that the differences in the trends in smoking-attributed mortality accounted for the differences in the overall change in female advantage. Although all three groups of countries exhibited an increase in the female advantage for non-smoking mortality, they differed in the degree of change in smoking-attributed mortality. The size of the decline in the female advantage in smoking-attributed mortality corresponded to the decline in the female advantage overall. As Pampel suggested: "These results support the claim that the narrowing sex differential in mortality found in some countries stems completely from smoking-attributable mortality at ages 35-69 and largely from smoking attributed mortality at ages 70 and older." All things considered, he believed, the narrowing differential in male and female smoking mortality was the result of the timing of the adoption of cigarette use, rather than gender equality. Advances in female longevity had fallen because large numbers of women had taken up smoking (Pampel, 2002).

\section{Factors behind the changing trends}

In order to understand and follow the Hungarian trends, we need to look at further factors behind historical examples. As has already been noted, the spread of the smoking epidemic has, perhaps naturally, not occurred at the same pace or with the same intensity in the various developed countries. Cultural and historical factors can be crucial to these processes: for instance, the engagement of a given population in global processes, the degree of openness of a society, the mentality, traditions, and level of tolerance of a given society in relation to anti-tobacco strategies. As Pampel (2002) states, differences in the price of tobacco products and the laws regulating them mean that some countries will peak at higher levels of smoking prevalence. Consequently, the same level of smoking could reflect an earlier stage in a high-smoking country but a peak stage in a low-smoking one. "The earlier cigarette diffusion begins, the later or more advanced the current stage; conversely, the later the process begins, the 
earlier or less advanced the current stage ... Great Britain's longer history of cigarette smoking means it has reached a more advanced stage in the diffusion process than Spain. During this late stage of diffusion, declining smoking among men and rising smoking among women should lead to small sex differences in mortality" (Pampel, 2002).

If from all the male smoking prevalence and smoking-attributable mortality values we subtract the appropriate female values, we get the gender gap. Because men are affected by smoking at an earlier phase in life, and because the pace of rising smoking prevalence differs by gender, the sex differences initially grow. Figure 3 shows that in the USA the gender gap increased steadily from the 1900s until the 1940s. As the tempo of smoking prevalence increase slowed for males, but increased steadily among women, the sex differential in smoking peaked at the time of World War II. After this, the prevalence stagnated in the 1950-1960s among men and continuously increased among women, consequently the sex differentials in smoking prevalence started to decline at that time. When the prevalence among both genders declined substantially from the 1970s, the gender gap started to narrow visibly, and, according to the estimations, the differential in smoking prevalence will have disappeared in the US by 2020. Accordingly, smoking-attributable mortality shows a similar trajectory - but with a delay of three decades: the gender gap grows from the starting point until the 1960s, peaks around the 1970s, and then decreases steeply up to recent years, when it reaches a minimum: complete gender equality in the effects of smoking in the USA. Pampel's (2002) conclusion is similar: the more advanced the stage of the epidemic, the smaller the sex difference in mortality. Moreover, he states that in making appropriate cross-national comparisons, what emerges as crucial is the stage of cigarette diffusion, rather than the level of gender equality.

Luy and Wegner-Siegmundt (2014) decomposed gender differences in life expectancy at birth into three components: biological factors, smoking, and other non-biological factors. The analysis covered 53 populations from developed countries, and 55 years of observation from 1955 to 2009. This research categorized Hungary as belonging to the group where both the trend and the extent of the gender gap are predominantly driven by smoking. In Austria and the USA, only the trend of the gender gap is predominantly driven by smoking, while the extent of the gender gap is predominantly driven by other non-biological factors. According to the conclusion of the authors, the contribution of smoking to the gender gap declines in all populations studied, although the beginning of the decline varies in accordance with the model of the smoking epidemic (Luy and Wegner-Siegmundt, 2014). 


\section{The situation in Hungary}

Figure 3 shows the situation in Hungary and the two reference countries. In terms of smoking prevalence, the largest gender differences are in Hungary, followed by Austria, and then the USA. If we look at the timeline, in all three cases there is a significant drop in prevalence and a trend towards gender equality in the last decades.

In the USA, the smoking mortality gender gap peaked around the 1970s, with a difference of more than $15 \%$. By contrast, the difference was at its greatest in Hungary three decades later, around the 2000s, and the size of the gap was larger than the USA had witnessed (over 20\%). On the one hand, the changes in the Austrian gender differences paralleled those in the USA, peaking in both cases around the 1970s (in the case of Austria, a little earlier); on the other hand, the extent of the Austrian gap was more similar in size to that of Hungary.

With respect to the size of the gender differences, these observations could possibly mean that in the past, gender roles were more traditional in Austrian and Hungarian society than in the USA. Of course, both Central European countries are rather similar to each other in this respect. Furthermore, with regard to the historical change in gender differences, Austria has been better integrated and better embedded in the economy of the developed Western countries than Hungary.

Figure 3: Gender differences in smoking prevalence and smoking-attributable mortality in the USA, Hungary, and Austria, 1900-2025

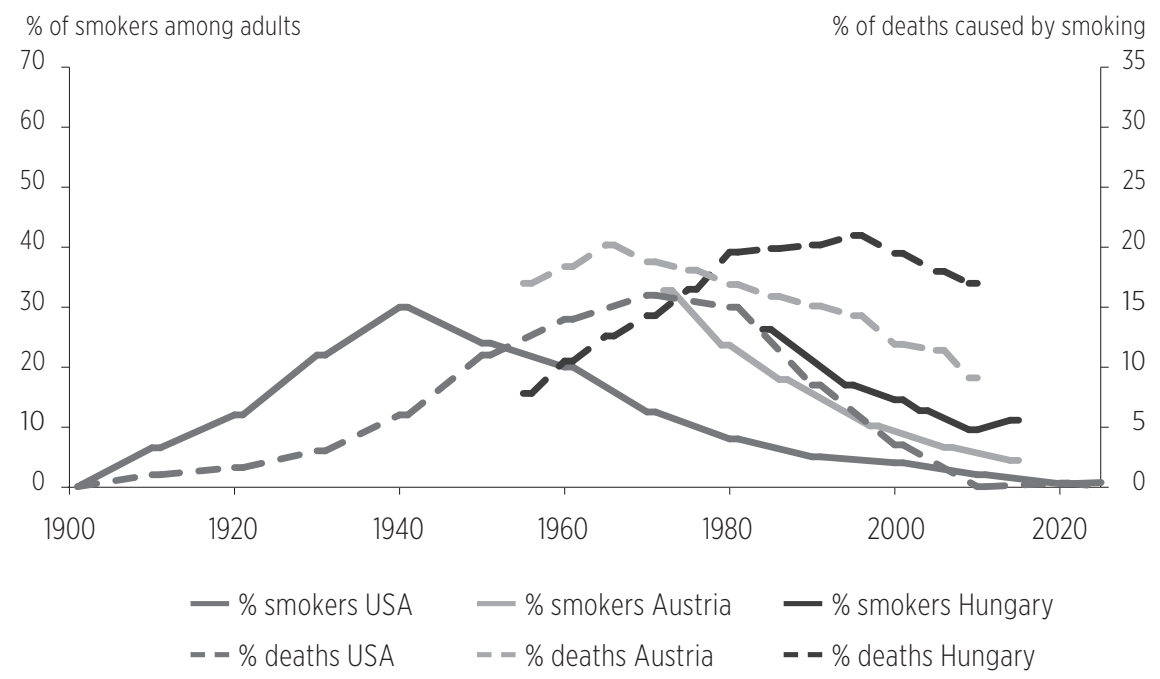

Source: See Appendix I. 


\section{SMOKING-ATTRIBUTABLE MORTALITY IN HUNGARY, 2000-2015}

\section{General trends by gender}

If we have access to the data on smoking prevalence in a population (by sex and age), the relative risks of tobacco-related causes of death, and the absolute number of deaths by cause of death, then we can calculate the smokingattributable (premature) mortality in a given year, according to the methods used for the official calculations at the American Centers for Disease Control and Prevention (USDHHS, 2014). ${ }^{3}$ These values have been estimated for Hungary from 2000 to 2015 by sex, age, and cause of death, and so this provides an opportunity to examine the trends in Hungary after the millennium. It is important to note that smoking prevalence data obviously originate from health interview surveys, and so confidence intervals of $95 \%$ are presented wherever possible. At the same time, this methodology assumes that nobody dies before the age of 35 as a result of tobacco consumption.

In Figure 4, we can see that the trend in general premature male mortality is downwards between 2000 and 2015 (by 29\%). Smoking-attributable deaths among men also decreased steadily, though to a lesser extent (only around a quarter). Consequently, tobacco-related mortality increased slowly as a percentage of all male premature deaths - from $32 \%$ to $34 \%$.

The picture of premature death among women is quite different, as their premature mortality is generally half that of men. Nevertheless, the basic trend declines similarly, though more modestly - by only $20 \%$. In contrast to the decline in male smoking-attributable mortality, among women there is a significant rise - of nearly a third. Because general female premature mortality has declined and tobacco-related deaths have grown, smoking-attributable mortality as a percentage of all female premature deaths has increased significantly - from $17 \%$ to $27 \%$.

As the figures for overall premature mortality improved more rapidly for men than for women, the gender gap decreased by more than a third in the period 2000-2015. Meanwhile, the difference in tobacco-related mortality decreased by $41 \%$. The change in the percentage of smoking-attributable mortality in the gender gap displays a more ambivalent picture: from 2000 until 2010, there was a continuous downward trend; but then the non-smoking gender gap started to

\footnotetext{
${ }^{3}$ See detailed method in Wéber (2017).
} 
decline faster than the tobacco-related one, and so the relevance of smokingattributable mortality in the gender gap started to grow again from 2011, and by 2015 it stood at around 40\%.

Figure 4: Premature (ages 35-69) smoking-attributable and non-smoking-attributable SDR/100000* by sex, and the gender gap in Hungary, 2000-2015
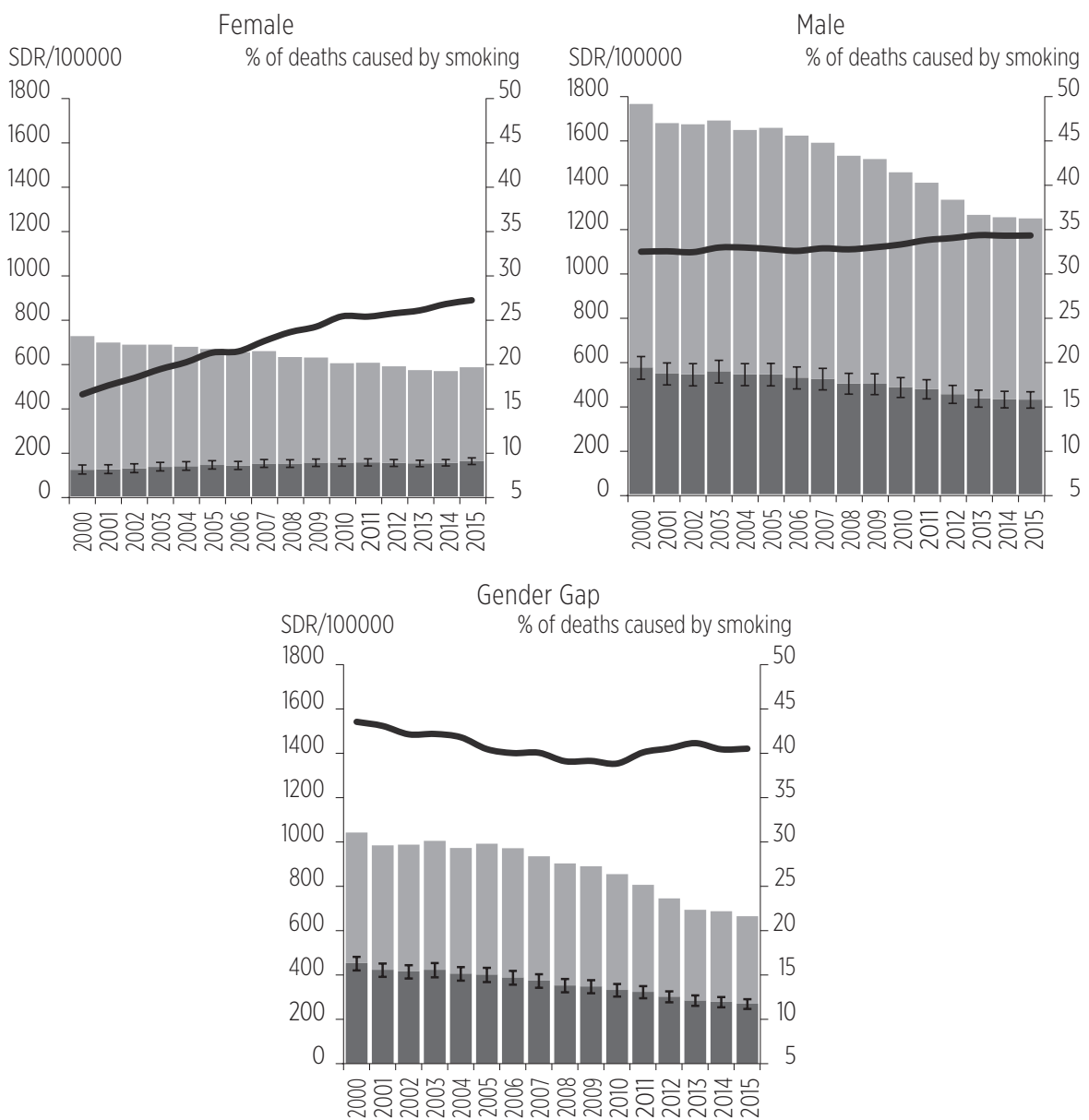

Non smoking-attributable deaths (expected)

Smoking-attributable deaths (expected)

— \% of smoking attributable mortality

* Standardized Death Rate per 100,000 inhabitants.

Source: Own calculations. Based on the mortality data of the Hungarian Death Register, the prevalence data are from the National Population Health Survey 2000 and 2003, European Health Interview Survey (EHIS) 2009 and 2014, the relative risks values are from USDHHS, 2014. 


\section{General trends by gender and age group}

Placing the total probability of dying (qx) on the vertical axis and the smokingattributable probability of dying (qxs) (see Appendix II) on the horizontal, time-path plots can be created to explore the changes in smoking-attributable mortality in Hungary by sex and age group. If the line runs up to the top-right corner, there is a clear deterioration in the age-specific mortality (both the indicators are worse); but if it runs to the bottom-left corner, it represents only positive developments (both the indicators are improving). Figure 5 shows that for males in all age groups we can observe a significant improvement both in total and in smoking-attributable mortality between 2000 and 2015. The opposite trend is visible among middle-aged and older women for tobacco-related deaths. An improvement can be observed in younger age groups between 35 and 45, and there is a positive reverse trend at age 45-49; but in the older age groups, there is a clear increase in smoking-attributable mortality that almost completely negates the decline in the total mortality of older (55-70) women between 2000 and 2015.

When from the male probability of death in each age group we subtract the corresponding female value, we get the gender gap. Using the time-path plots again, it is clear that the sex difference in all age groups declined sharply between 2000 and 2015.

Figure 7 illustrates how smoking-attributable mortality contributed to the change in premature mortality in Hungary by sex and age group between 2000 and 2015.

The bar chart reveals that in all male age groups, the ratio of premature death decreased substantially, helped along by the decline in tobacco-related mortality. As age increases, so the drop is more notable. The greatest fall occurred in the generation aged 60-69; however, the contribution of the smoking-attributable decrease to the drop in premature deaths is proportionately more relevant in younger age groups - 45-49 and 50-54.

In this respect, the situation of women also differs from that of men, and the development between 2000 and 2015 can be divided into two parts. On the one hand, among those under 50 years of age, the decrease in tobaccorelated deaths contributed to the decline in premature female mortality; on the other hand, among those over 50, the increase in smoking-attributable mortality retards development in the field of premature female death. The results indicate that there are fundamental differences in the degree of health awareness between the younger and the older parts of the Hungarian female population. 
Figure 5: Probability of dying of total and smoking-attributable mortality, by sex and age group, from 2000 to 2015 in Hungary
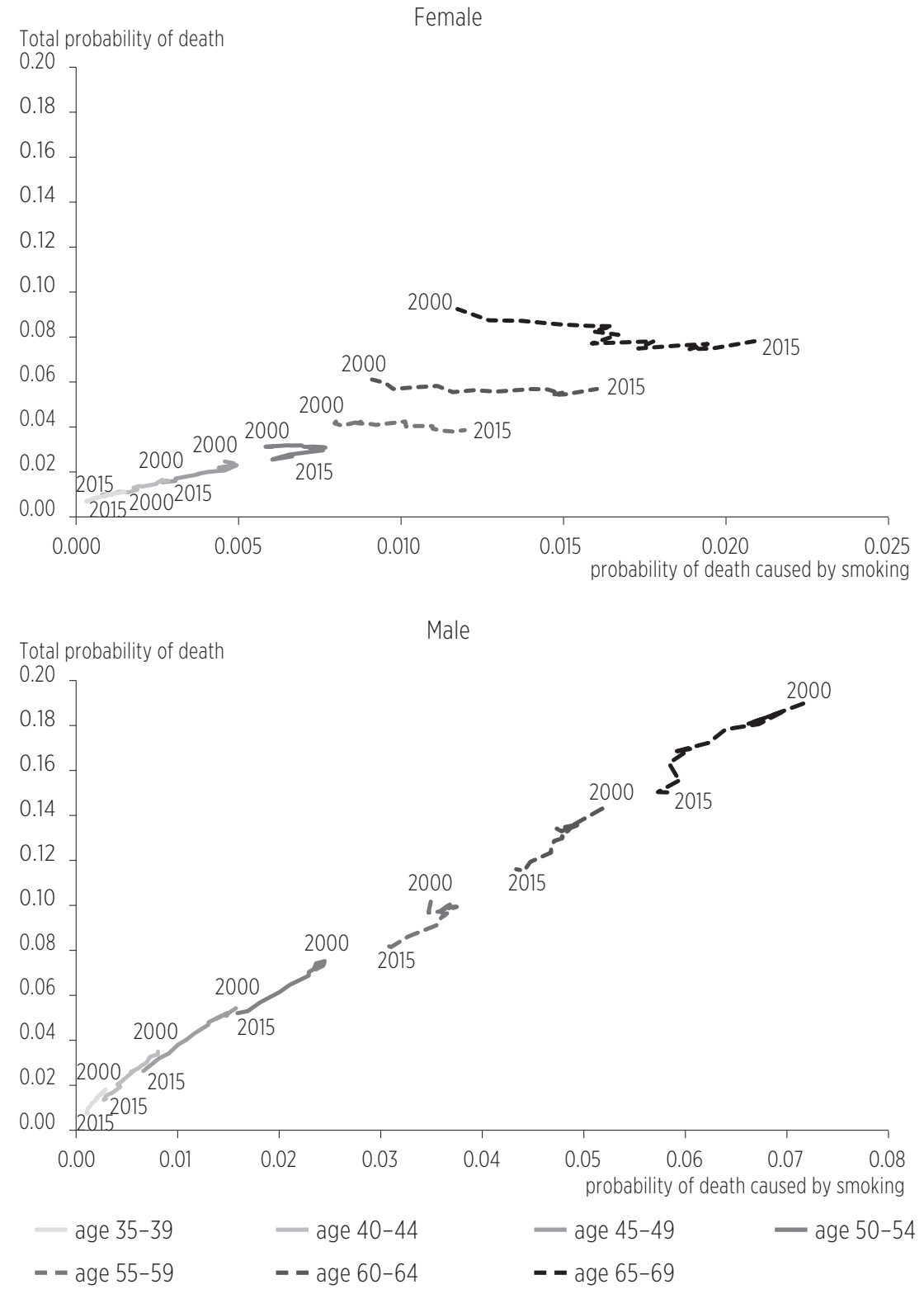

Source: Own calculations. Based on the mortality data of the Hungarian Death Register, the prevalence data are from the National Population Health Survey 2000 and 2003, European Health Interview Survey (EHIS) 2009 and 2014, the relative risks values are from USDHHS, 2014 
Figure 6: Gender differences in probability of dying of total and smoking-attributable mortality, by age group, from 2000 to 2015 in Hungary

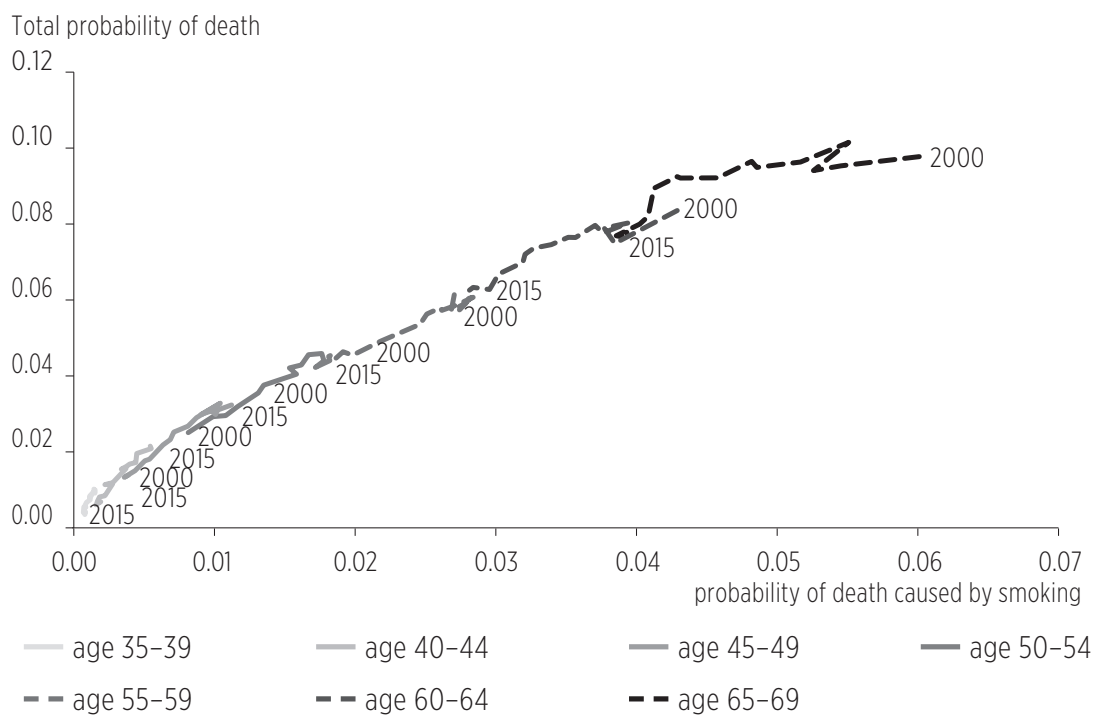

Source: Own calculations. Based on the mortality data of the Hungarian Death Register, the prevalence data are from the National Population Health Survey 2000 and 2003, European Health Interview Survey (EHIS) 2009 and 2014, the relative risks values are from USDHHS, 2014.

Figure 7: Changes in the age-specific death ratio/100000 between 2000 and 2015, by sex, age group, and smoking in Hungary (95\% confidence intervals)

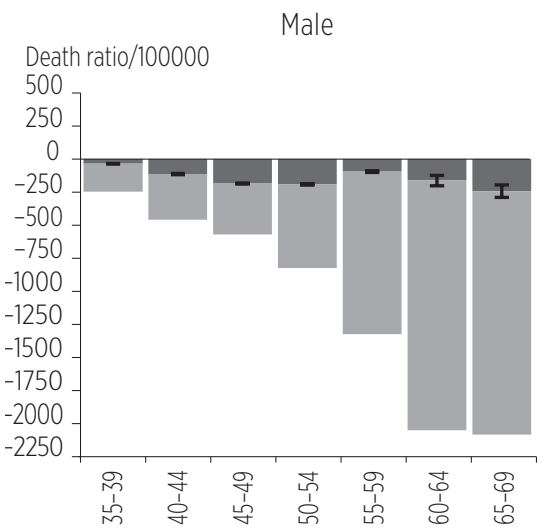

Age-specific non smoking-attributable mortality

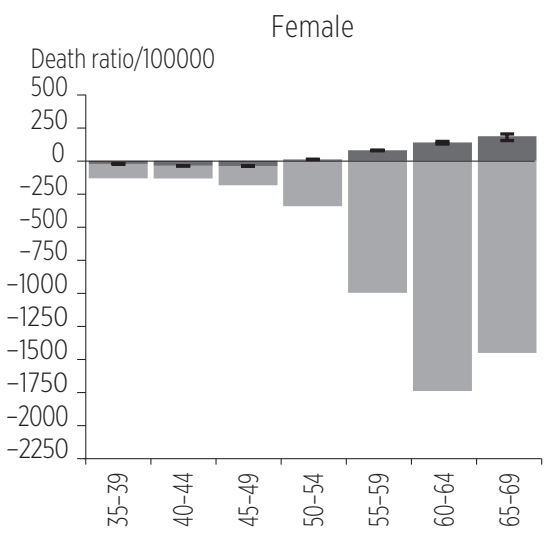

Age-specific smoking-attributable mortality

Source: Own calculations. Based on the mortality data of the Hungarian Death Register, the prevalence data are from the National Population Health Survey 2000 and 2003, European Health Interview Survey (EHIS) 2009 and 2014, the relative risks values are from USDHHS, 2014. 


\section{General trends by gender, age group, and cause of death}

From the point of view of public health, it is not only the age of the deceased smoker that is an important question, but also the cause of death. First of all, it should be mentioned that the method of data processing in Hungary changed in 2005, when the manual method was replaced by automatic processing, where the coding of death certificates and the primary cause of death reported in the statistics are electronically selected. Because of this, in the time series there is an artificial break in the trends between 2004 and 2005.

The methodology of the CDC (updated in 2014) - as expressed in its ICD-10 codes - distinguishes 90 different causes of death related to tobacco consumption (USDHHS, 2014). These causes can be grouped into larger categories. This paper takes account of the most frequent - mainly chronic diseases (for instance, cancers and cardiovascular diseases) - in accordance with the general structure of causes of death in countries with an advanced health culture. ${ }^{4}$

Figure 8 focuses on the smoking-attributable part of Figure 4, and breaks down the information by cause of death.

The values of all causes of male smoking-attributable death have declined, except for the group of bronchitis, emphysema, and COPD (Figure 8: bar chart, top left). Lung, bronchus, and trachea cancers are the most relevant, at around $30 \%$, and since 2000 the value has not changed substantially (Figure 8: line chart, bottom left). The stagnant trend for other cancers is similar, although their importance is only around half that of lung, bronchus, and trachea cancers. A significant and similar (around 3-4 percentage points) decrease can be observed in the relevance of ischemic heart diseases and other smoking-attributable deaths. Conversely, the importance of bronchitis, emphysema, and COPD causes of death almost doubled between 2000 and 2015, reaching more than $11 \%$.

The trends in female tobacco-related mortality by cause of death differs slightly from the pattern observed among males. The most important fact is that (unlike men) the Standardized Death Ratio (SDR) values for lung, bronchus, and trachea cancer and for bronchitis, emphysema, and COPD have increased dramatically since 2000 (Figure 8: bar chart, top center). If we talk of the relative relevance of these factors in female smoking-attributable mortality, the situation appears even more critical. The proportion of lung, bronchus, and trachea cancer

\footnotetext{
${ }^{4}$ At this stage of the analysis, the $95 \%$ confidence intervals are not displayed in the diagrams, due to problems with their visual representation, only the calculated expected values.
} 
rose from a figure of approximately 30\% to 40\% between 2000 and 2015, while the incidence of bronchitis, emphysema, and COPD as the cause of death doubled among women (from 8\% to 16\%), similar to that among men (Figure 8: line chart, bottom center). Furthermore, gender makes no difference in the decline of other forms of cancer to stagnation, or in the ratio of ischemic heart diseases and other smoking-attributable deaths.

Taking all this into account, over the past decade and a half, the relative weight of lung, bronchus, and trachea cancers in the gender gap has decreased somewhat to reach a similar level to that of ischemic heart diseases, which have stagnated since 2000 (Figure 8: line chart, bottom right). The same stability can be observed when one considers other smoking-attributable diseases, and a slight increase can be observed in the importance of other cancers and bronchitis, emphysema, and COPD as causes of death.

Using the same time decomposition method with time-path plots as in Figure 5 by sex, age group, and cause of death, we see very interesting developments appearing in Figure 9 for men and in Figure 10 for women.

Between 2000 and 2015, almost all the male smoking-attributable causes of death declined in every age group (Figure 9), except for bronchitis, emphysema, and COPD deaths in the age groups 55-64, which increased between 2000 and 2015. It is important to emphasize the role of other forms of cancer, which remained more or less the same among men in their 60s.

Most of the female smoking-attributable causes of deaths show a decrease between the ages of 35 and 49 in the period observed (Figure 10). Over 50 generally, lung, bronchus, and trachea cancers and bronchitis, emphysema, and COPD smoking-attributable mortality decreased. From the age of 55, ischemic heart diseases and other types of cancer show negative tendencies and from 65 to 69 the other smoking-related diseases also show a rising trend.

It is worth mentioning that this decomposition method shows how much the importance of various "smoking-attributable" causes of death increased from 2014 to 2015 due to the flu epidemic at the beginning of 2015.

In Figure 11, where the changes in gender differences can be observed between 2000 and 2015, in almost all smoking-attributable causes of death there is a shrinking gender gap. Perhaps the only exception is bronchitis, emphysema, and COPD diseases, where there was no change in the gender differences in the over 40 s after the turn of the millennium. 


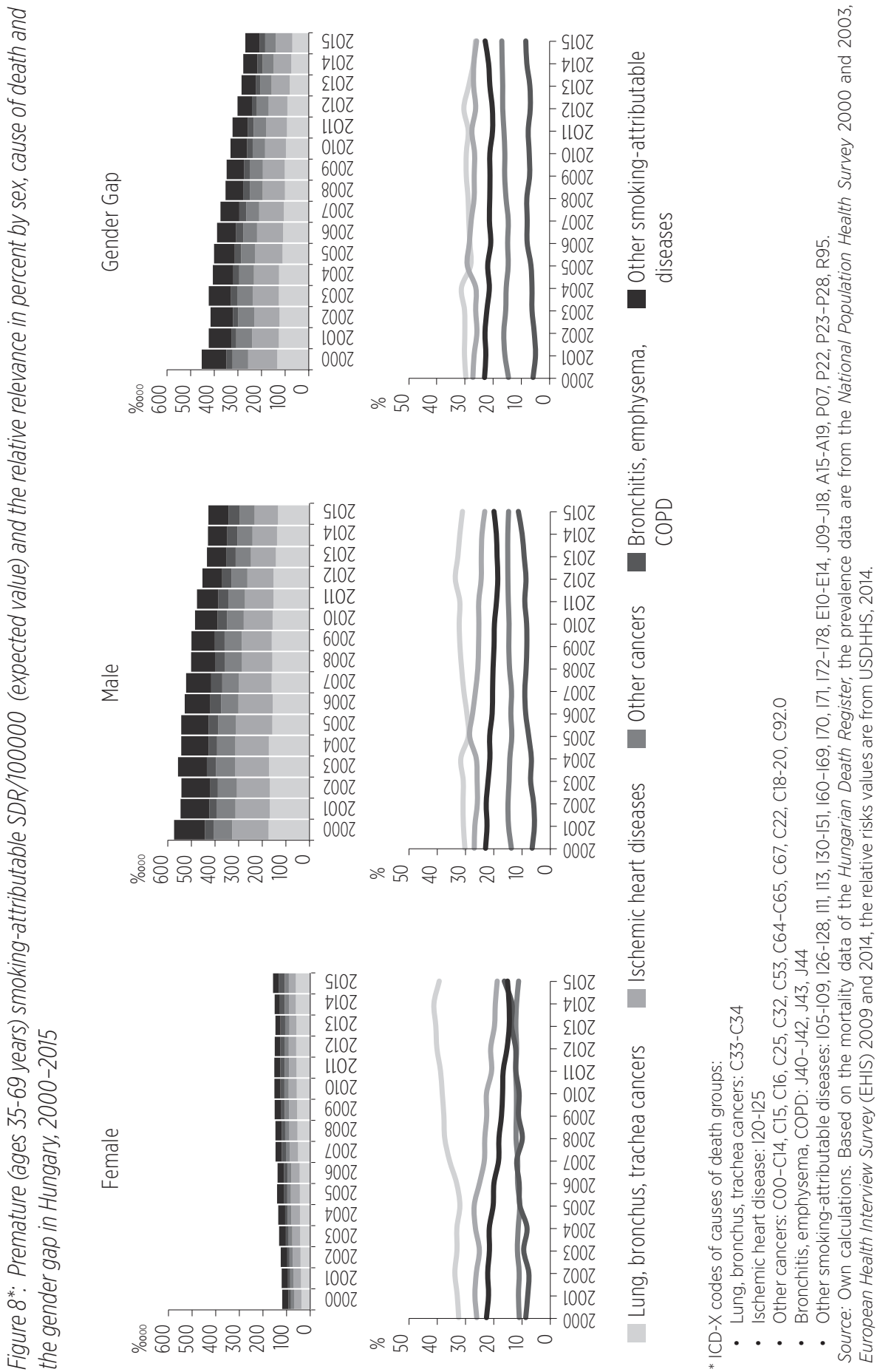




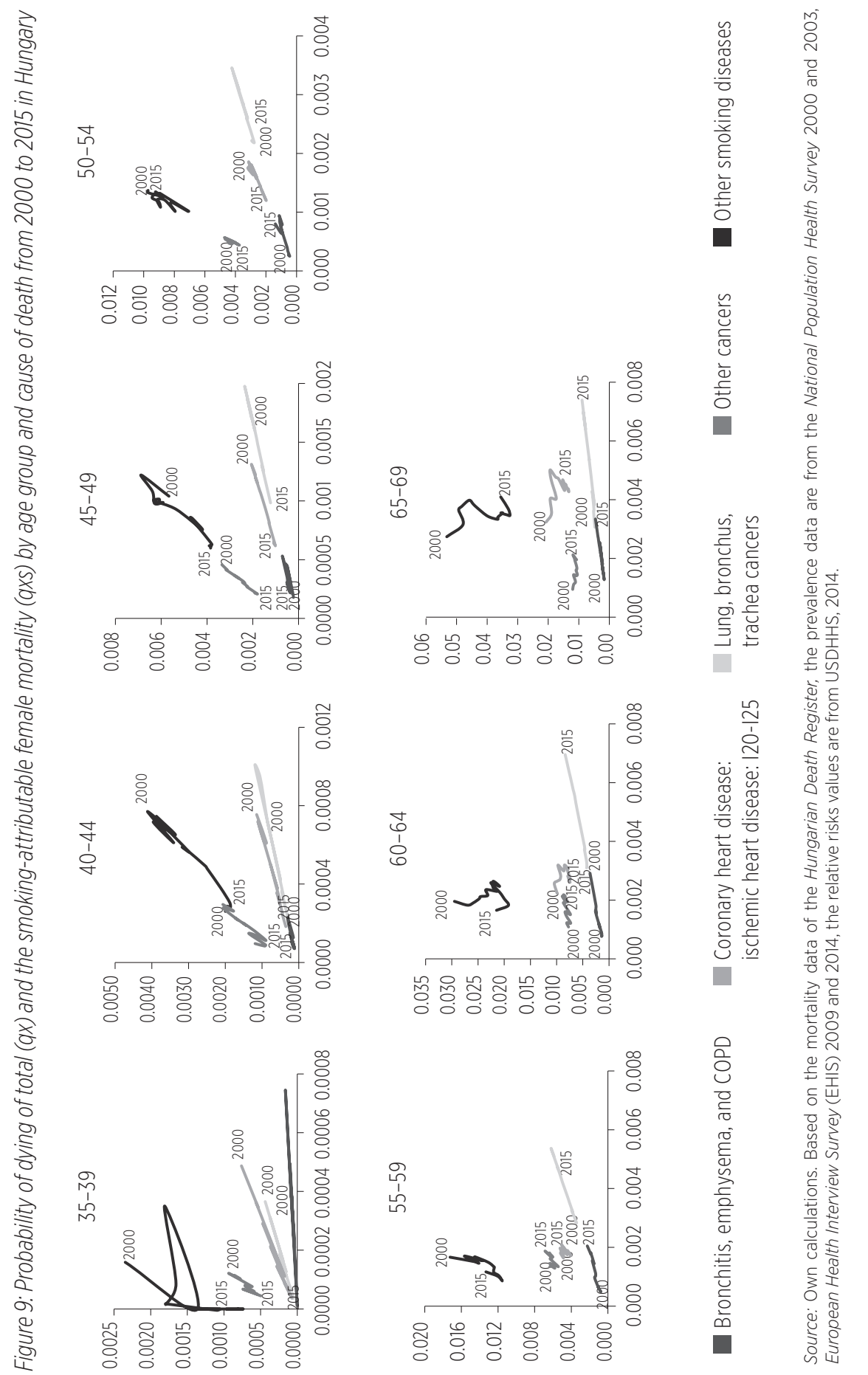




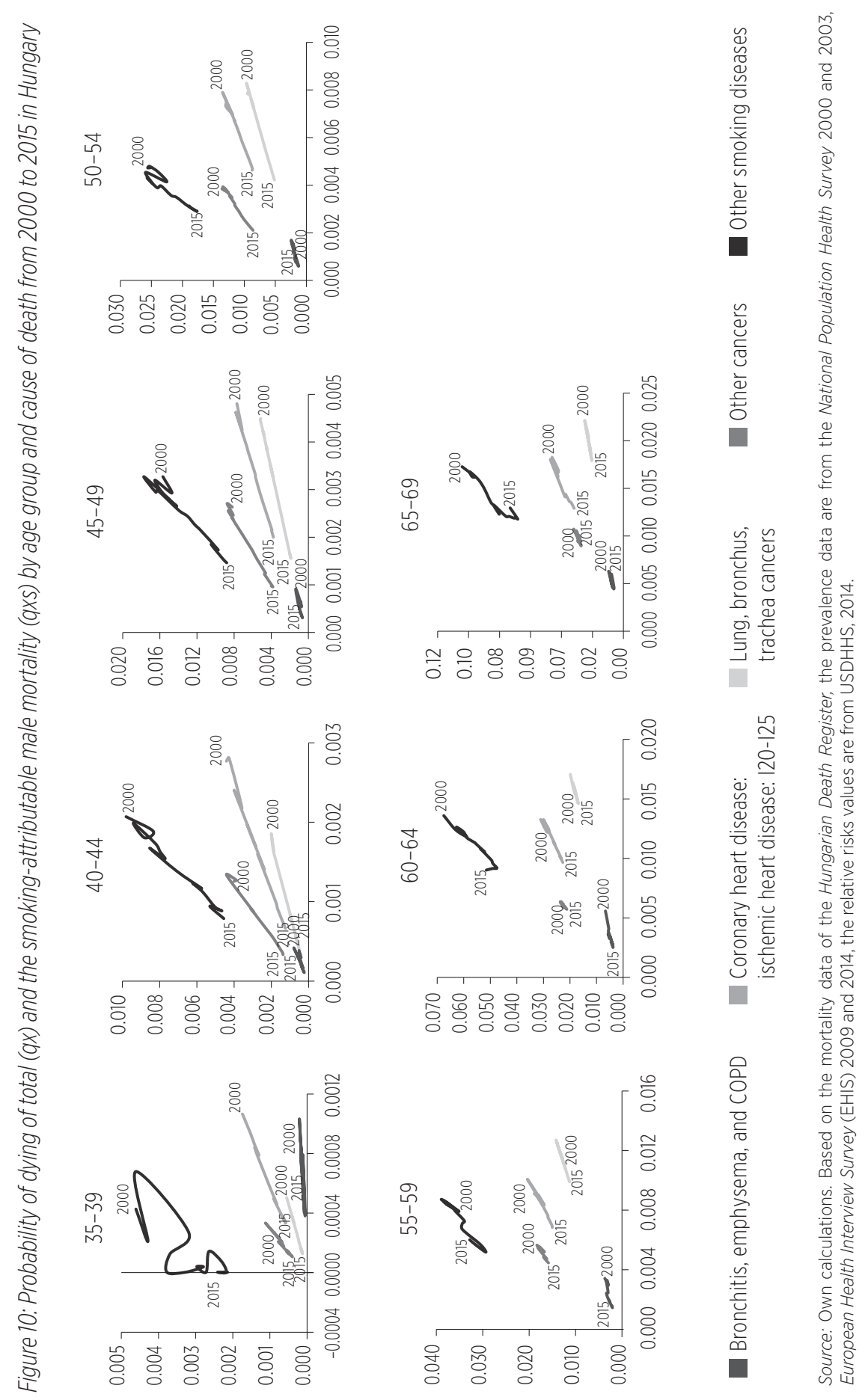




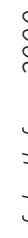
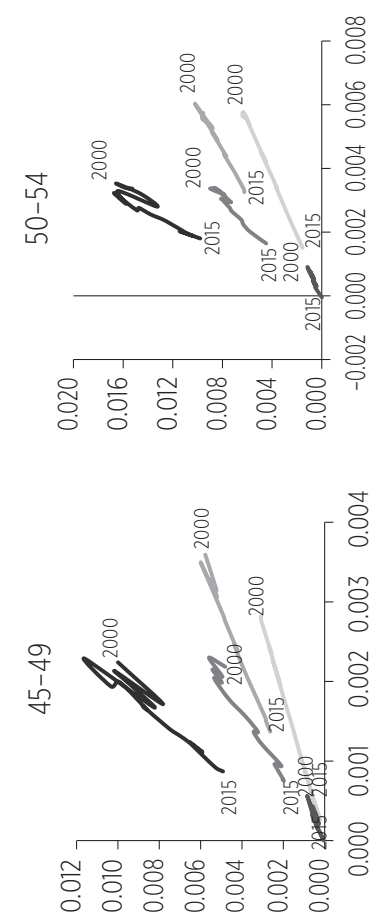

象事

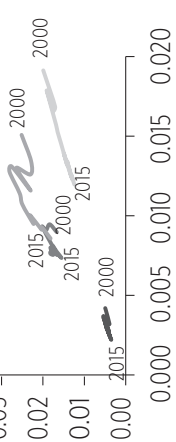

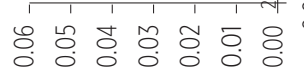
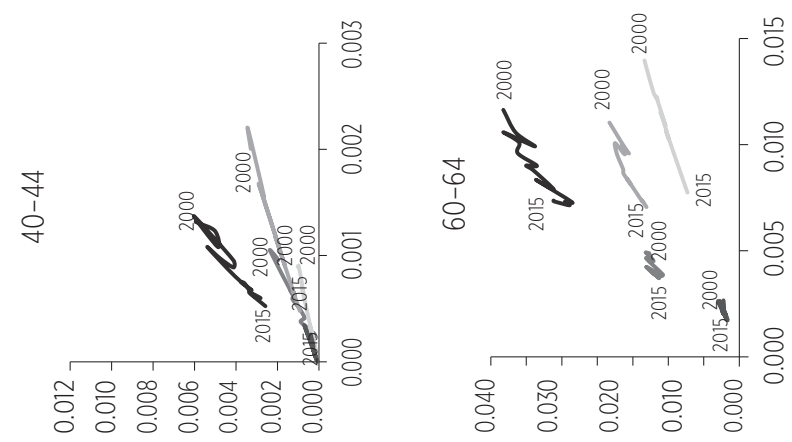

응

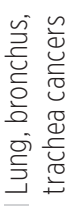

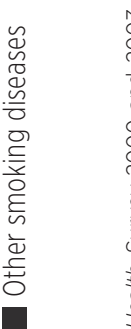

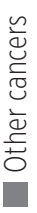

ले

웅

㐫

密

$\frac{\text { 焉 }}{\frac{2}{1}}$

$\frac{\sqrt{\frac{1}{2}}}{\frac{1}{2}}$

鹿

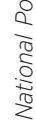

$\stackrel{\oplus}{\mp}$

ह

$\frac{\sqrt{\circ}}{\frac{10}{4}}$

$\frac{\pi}{0}$

过

d

这

बँे

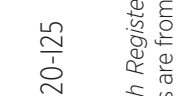

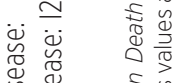
凹

들

它 离

त्र

든

ㅎํ는

흘

용

()

ᄃㅍ

일

藏

농 d

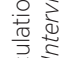

剀

赵过

ก

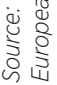


Figure 12 shows the changes in premature smoking-attributable mortality by age group and cause of death between 2000 and $2015 .{ }^{5}$

As has already been seen in the case of men, as age rises, so smokingattributable deaths contribute more and more to the significant decrease in premature mortality; but developments in the cause of death cast something of a shadow over the picture.

On the one hand, the decrease in tobacco-related lung, bronchus, and trachea cancers, ischemic heart disease, and other smoking-attributable diseases in all age groups - and in other cancers between 35 and 59 - has contributed to a decline in premature smoking-attributable male mortality. On the other hand, an exceptional increase is to be seen in tobacco-related bronchitis, emphysema and COPD mortality between the ages of 55 and 69; this substantially slowed the improvement in premature smoking-attributable conditions in the corresponding male age groups in the period under analysis.

Figure 12: Changes in the smoking-attributable age-specific death ratio/100000 between 2000 and 2015, by sex, age group, cause of death in Hungary

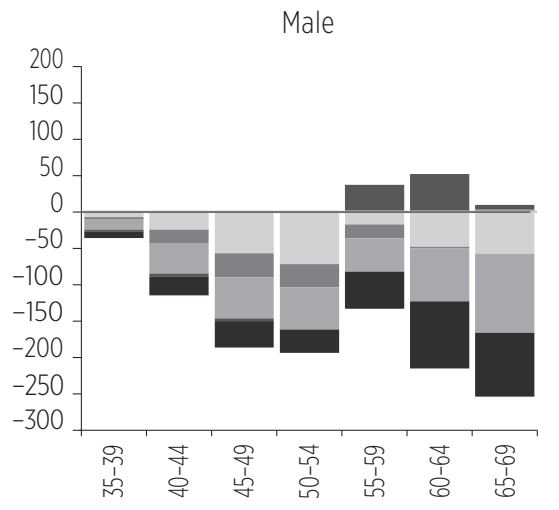

Lung, bronchus, trachea cancers

Bronchitis, emphysema, COPD

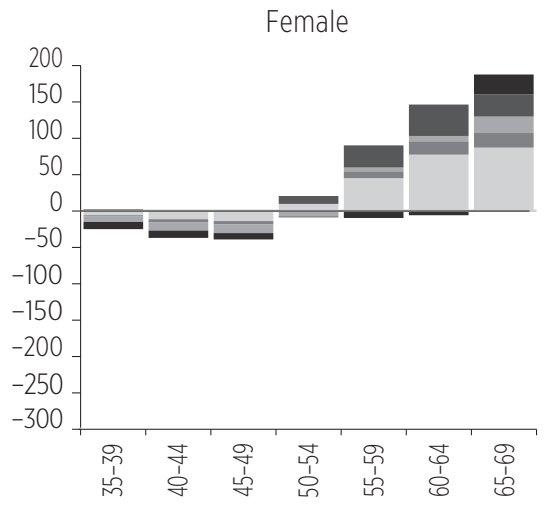

Other eancers

Coronary heart disease

Other smoking-attributable diseases

Source: Own calculations. Based on the mortality data of the Hungarian Death Register, the prevalence data are from the National Population Health Survey 2000 and 2003, European Health Interview Survey (EHIS) 2009 and 2014, the relative risks values are from USDHHS, 2014.

${ }^{5}$ The chart is formally similar to Figure 6, the difference is just that Figure 11 particularizes the dark-colored part of the mentioned graph. 
The mortality situation of Hungarian middle-aged female smokers appears critical. First, the rising occurrence among those aged over 50 of tobaccorelated lung, bronchus, and trachea cancers, and bronchitis, emphysema, and COPD deaths has to be emphasized; this high level of occurrence rises ever more steeply with increasing age. Secondly, from the age of 55, other cancers and ischemic heart disease contribute more and more to the deteriorating picture, as the female smoker population ages.

\section{FOCUSING ON WOMEN}

\section{Basic theories}

As we have seen, there are fundamental gender differences in the development of the smoking epidemic - including in the changes in premature smokingattributable mortality. Put simply, bearing in mind the descriptive model of the cigarette epidemic, with its separate stages, recently we have witnessed a generally improving trend among men and a worsening trend among women. The problem is even more complex than it would appear at first sight: as Waldron (1991) suggests, historically improvements in women's rights and in gender equality have contributed to an increased acceptance of women smoking; but currently in our time, this relationship between smoking and attitudes toward women's rights and roles remains unclear. In terms of diffusion, it suggests that restrictions on women's behavior in the early twentieth century contributed to the later spread of smoking among women, rather than among men.

Amos and Haglund (2000) examined this problem from a gender perspective. In their opinion, it is remarkable that within 50 years of the introduction of the mass-produced cigarette, smoking among women in North America and northern Europe had become socially acceptable - even socially desirable. This was due not only to the dramatic changes in the social and economic status of women over this period, but also to the way in which the tobacco industry capitalized on the changing social attitudes toward women by promoting smoking as a symbol of emancipation - a "torch of freedom". Moreover, in their paper they point out Hungary's particular exposure to this serious problem:

"Some of the most blatant commercial targeting of women has occurred in the former socialist countries of Central and Eastern Europe, which are now exposed to the forces of 'free' markets, and which have the highest rates of female smoking in the world. Here cigarettes are promoted to 
women as a potent symbol of Western freedom, as in 'Test the West.' In Hungary, the slogan is 'Lady's first' (sic), while in the Czech Republic young women are encouraged to join men in their Western male leisure pursuits. Smoking rates among young women in these countries are increasing much more rapidly than in countries where smoking took off earlier this century" (Amos and Haglund, 2000).

Pirie et al. (2013) made a quantitative analysis of the increasing prevalence of female smoking. In their study, a huge number of UK women - 1.3 million - were recruited in 1996-2001 and resurveyed postally about three and eight years later. All were followed up until 2011 through national mortality records. Participants were asked, when they first joined the survey group, whether they were current or ex-smokers, and how many cigarettes they currently smoked.

The researchers came up with three main conclusions, following analysis of the data. First, during the 12-year mortality follow-up, those who had been current smokers at baseline had an overall mortality rate that was almost three times the rate of those who had never smoked. Secondly, the age at which women first started smoking regularly affected overall mortality decades later: those who had started at about age 15 were at greater risk than those who started only four years later. Thirdly, smokers who stop at about the age of 40 avoid about $90 \%$ of the excess hazard among continuing smokers, whereas those who stop at about the age of 30 avoid about $97 \%$ of it (Pirie et al., 2013).

In their study, Gregoraci et al. (2017) measured socioeconomic inequalities in smoking-attributable mortality and their contribution to inequalities in total mortality in 1990-1994 and 2000-2004 in 14 European countries. They found that since 1990-1994, absolute inequalities in smoking-attributable mortality and the contribution of smoking to inequalities in total mortality had both decreased in most countries among men, but had increased among women. According to their conclusions, in many European countries, smoking has become less important as a determinant of socioeconomic inequalities in mortality among men, but not among women (Gregoraci et al., 2017).

\section{Women in Hungary}

The age-specific smoking-attributable mortality analysis revealed that the situation of Hungarian women aged 50-70 worsened significantly between 2000 and 2015; meanwhile, in the younger age groups, a slight improvement can 
be observed. This shows the presence of a strong cohort effect in the Hungarian population, meaning that the female cohorts born between 1945 and 1965 are more affected by the habit of smoking and are generally more likely to persist with unhealthy lifestyles and other risk factors, carrying them over from the past. But, of course, the overall picture is more complex. For instance, with the collapse of state socialism, this generation quite suddenly found itself part of a new world order in the early 1990s. Faced with increasingly individualized and competitive conditions, Hungarian women had to rebuild their own individual strategies. At the same time, these goals could contradict family and gender relationships, and the division of labor within the family.

Utasi (2011) examined the factor of subjective tension and work stress in the life of married women in 24 European countries, based on the 2005 European Social Survey. The key concept of her analysis was the "double workload" (a notion that originated with the early suffragettes; and indeed Marx and Engels used the expression "the double burden", as it is usually translated, in their works on female emancipation as long ago as the 1870 s and 1880s). This refers to family tension arising from the reconciliation of housework and paid labor, and to the fact that women are more exposed to this effect. According to multidimensional research, the overwhelming majority of countries with high levels of work-related stress are in the former socialist bloc. According to Utasi, the responses of people living in Central and Eastern Europe are colored by fear of losing their jobs - a fear that is much more prevalent in the post-transition period than previously. However, it should also be noted that while Central and Eastern European women and men both experience the highest reported level of work-related stress, wives in this region still report significantly higher levels of negative stress than husbands, since female emancipation is less advanced. Traditional expectations in terms of the division of labor at home are higher, while the technical-civilization level is lower than in other regions (Utasi, 2011).

Lurking behind the worsening smoking-attributable situation of middle-aged and older women could be the accelerated emancipation and the blurring of the borders between gender roles. At the same time, the higher rate of premature death among men, alongside the phenomenon of divorce, may fundamentally alter the family ties and situation of middle-aged women. Coping with the new situation could lead to greater stress, which could encourage women smokers to increase their tobacco consumption. 


\section{POSSIBLE POLICY SOLUTIONS}

Anti-tobacco strategies aim at reducing the negative effects of cigarette consumption in the whole population, and especially among the younger age groups. This paper nonetheless clearly demonstrates that the most important field of intervention in social policy should be to reduce smoking among women. This is also confirmed by the delay in Hungarian and Austrian female smoking prevalence peaks in the 2000s, compared to trends in the United States. The most important step in any anti-tobacco strategy would be to persuade smokers (especially women) to quit smoking (or if that does not work, then to cut back radically on the amount consumed) and to prevent younger generations from ever beginning the addiction. As Bray et al. (2004) state, it is imperative that anti-tobacco strategies should urgently target women living in the EU, in order to halt their rapidly increasing risk of lung cancer, and prevent unnecessary, premature deaths among future generations of women. Furthermore, Amos and Haglund (2000) emphasize that building support for women-centered tobacco control programs through partnerships will be vital to achieve success.

Tyczynski et al. (2004) recommend a package of measures to suppress tobacco consumption in a given population. In their opinion, the two most important thrusts should be, first, to continue efforts to increase the proportion of ex-smokers, and secondly, to concentrate on younger generations. This could perhaps be achieved by implementing coordinated smoking prevention and control strategies from an early age, in particular in the form of educational programs in schools. In their opinion, these programs should focus not only on children (adolescents), but also on parents and teachers. Other measures that could be introduced include community intervention programs, mass media campaigns, appropriate fiscal policies (regulation of prices via tobacco excise taxes), and - last but not least - further legislation to ban smoking in public places. They suggest that one of the main problems is that young people react very differently to anti-smoking messages than do adult long-term smokers; armed with knowledge of youth attitudes to smoking, the tobacco companies are constantly developing more effective ways of selling tobacco products to young people (Tyczynski et al., 2004). It is very important to tackle this manipulation, given the point made by Pirie et al. (2013) that by far the greatest part of the excess risk of death due to smoking in middle and old age can be avoided by quitting before the age of 40 (or preferably long before that). 


\section{CONCLUSIONS}

We used Hungarian, Austrian, and American data to gain a comparative picture of the Hungarian situation. In the case of Hungarian men, the initial advance and subsequent retreat of the smoking epidemic is evident; this is largely due to the epidemiological crisis characteristics of Hungarian society before the regime change in 1989. In the case of women, more traditional gender roles previously dominated society in Austria and Hungary in a way that was different from the USA; these social norms to some extent protected Central and Eastern European women from even greater harm arising from the cigarette epidemic. But at the same time, the picture is complex: in the over-50 age groups, the increased smoking-attributable mortality is holding back improvement in women's early mortality. Furthermore, the critical tobacco-related causes of death have been identified in Hungary from 2000 until 2015 in some detail. The results demonstrate that there are fundamental differences in the degree of health awareness between the younger and the older cohorts of the Hungarian female population. If we examine this problem more closely, we find that middleaged and older Hungarian women smokers were the unprotected population targeted by the tobacco industry in the critical and challenging times around the regime change. Analysis shows that a strong cohort effect can be observed in the Hungarian population, meaning that female cohorts born between 1945 and 1965 are more affected by the habit of smoking and its consequent harm, and this is probably also related to the phenomenon of the "double workload." The research shows that - due to the progress and nature of the smoking epidemic sex differences in Hungary are going to decrease substantially in the future. This is also supported by the results of the smoking-attributable mortality figures, where in every age group, and for almost all causes of death, the sex differences have declined sharply in Hungary since the turn of the millennium.

Anti-tobacco strategies should protect the whole population (particularly the younger generations) from the negative effects of cigarette consumption; but this paper also clearly demonstrates that the most important policy intervention ought to be the prevention and reduction of smoking in the female population. Bearing this in mind, this research suggests numerous social-political steps to suppress the negative effects of the cigarette epidemic, taking into account the recommendations of, among others, Tyczynski et al., Amos and Haglund, and Thun et al. 
Hungary is a country struggling with the negative inheritance of the socialist era. Nevertheless, it has been able to make some efforts in the recent past to protect its population against the spread of the smoking epidemic - for instance, the steady increase in the extra tax on tobacco and the smoking ban in all enclosed spaces since 2012; but there should be no let-up in the battle against the smoking epidemic. As Vokó (2009) states, effective means of combating smoking are well known. Hungary has taken some important steps in the past two decades, but these have been too little and not effective enough. Stopping this entirely preventable epidemic must now rank as a top priority in public health policies (Vokó, 2009). This research has demonstrated that the female population should be a key target for policy intervention. 


\section{REFERENCES}

Amos, A. and Haglund, M. (2000). From social taboo to "torch of freedom": the marketing of cigarettes to women. Tobacco Control, 9(1), pp. 3-8.

Balku, E. and Varsányi, P. (2016). Az aktív és passzív dohányzás társadalmi és gazdasági terhei. [The social and economic burdens of active and passive smoking] In: T. Demjén, ed., Dohányzás visszaszorítása. [The suppression of smoking] Budapest: Dohányzás Fókuszpont, Nemzeti Egészségfejlesztési Intézet (NEFI).

Bőti, E., Koncz, B. and Vitrai, J. (2011). A felnőttek dohányzására vonatkozó magyarországi felmérések adatai, 2000-2009. [Hungarian survey data on smoking by adults, 2000-2009] Budapest: Dohányzás Fókuszpont, Országos Egészségfejlesztési Intézet (OEFI).

Bray, F., Tyczynski, JE. and Parkin, DM. (2004). Going up or coming down? The changing phases of the lung cancer epidemic from 1967 to 1999 in the 15 European Union countries. European Journal of Cancer, 40(1), pp. 96-125

Carlson, E. and Hoffmann, R. (2011). The State Socialist Mortality Syndrome. Population Research and Policy Review, 30(3), pp. 355-379.

Doll, R. and Hill, AB. (1950). Smoking and the carcinoma of the lung. British Medical Journal, 2(4682), pp. 739-748.

Gregoraci G., van Lenthe FJ., Artnik B. et al. (2017). Contribution of smoking to socioeconomic inequalities in mortality: a study of 14 European countries, 1990-2004. Tobacco Control, 26(3), pp. 260-268.

Jha, P. and Peto, R. (2014). Global effects of smoking, of quitting and taxing tobacco. The New England Journal of Medicine, 370(1), pp. 60-68.

Józan, P. (2008). Válság és megújulás a második világháború utáni epidemiológiai fejlódésben Magyarországon. [Crisis and renewal in epidemiological development after World War II in Hungary]. Budapest: MTA Társadalomkutató Központ.

Józan, P. and Radnóti, L. (2002). A dohányzás hatása a halandóságra Magyarországon 1970-1999. [The impact of smoking on mortality in Hungary 1970-1999] Budapest: $\mathrm{KSH}$ (HCSO).

Kubík, A., Plesko, I. and Reissigová, J. (1998). Prediction of Lung Cancer Mortality in Four Central European Countries, 1990-2009. Neoplasma, 45(2), pp. 60-67.

KSH (2014). A haláloki struktúra változása Magyarországon 2000-2012 [Changes in the Structure of Causes of Deaths in Hungary 2000-2012]. Budapest: HCSO.

KSH (2016). Népesedési Helyzetkép, 2015 [Demographical Situation, 2015]. Budapest: $\mathrm{HCSO}$.

Lopez, AD. (1983). The sex mortality differential in developed countries. In A.D. Lopez and L.T. Ruzicka, eds., Sex Differentials in Mortality: Trends, Determinants and Consequences. Canberra: Australian National University, pp. 53-120.

Lopez, AD., Collinshaw, NE. and Piha, T. (1994). A descripitive model of the cigarette epidemic in developed countries. Tobacco Control, 3(3), pp. 242-247.

Luy, M. and Wegner-Siegmundt, C. (2014). The impact of smoking on gender differences in life expectancy: more heterogeneous than often stated. European Journal of Public Health, 25(4), pp. 706-710. 
Meslé, F. and Vallin, J. (2017). The End of East-West Divergence in European Life Expectancies? An Introduction to the Special Issue. European Journal of Population, 33(5), pp. 615-627.

Pampel, FC. (2002). Cigarette use and the narrowing sex differential in mortality. Population and Development Review, 28(1), pp. 77-104.

Peto, R., Lopez, AD., Boreham, J., Thun, M. and Heath, C. (1992). Mortality from tobacco in developed countries: indirect estimation from national vital statistics. Lancet, 339(8804), pp. 1268-1278.

Peto, R., Lopez, AD., Boreham, J. and Thun, M. (2012). Mortality from tobacco in developed countries 1950-2010. Supplementary data. In: Thun, M., Peto, R., Boreham, J. and Lopez, AD. (2012). Stages of the cigarette epidemic on entering its second century. Tobacco Control, 21, pp. 96-101. Available at: https://tobaccocontrol.bmj.com/highwire/ filestream/146943/field_highwire_adjunct_files/0/tobaccocontrol-2011-050294-s1.pdf

Pirie, K., Peto, R., Reeves, GK., Green, J and Beral, V. (2013). The 21 ${ }^{\text {st }}$ century hazards of smoking and benefits of stopping: a prospective study of one million women in the UK, Lancet, 381, pp. 133-141.

Shultz, JM., Novotny, TE. and Rice, DP. (1991). Quantifying the disease impact of cigarette smoking with SAMMEC II software. Public Health Reports, 106(3), pp. 326-333.

Thompson, CA., Waldhör, T., Schernhammer, ES., Hackl, M., Vutuc, C. and Haidinger, G. (2012). Smoking and lung cancer: current trends in Austria. Wiener klinische Wochenschrift, 124(15-16), pp. 493-499.

Thun, M., Peto, R., Boreham, J. and Lopez, AD. (2012). Stages of the cigarette epidemic on entering its second century. Tobacco Control, 21(2), pp. 96-101.

Tombor, I., Paksi, B., Urbán, R., Kun, B., Arnold, P., Rózsa, S. and Demetrovics, Zs. (2010). A dohányzás epidemiológiája a magyar népesség körében országos reprezentatív adatok alapján. [The epidemiology of smoking in the Hungarian population based on representative data] Orvosi Hetilap, 151(9), pp. 330-337.

Trovato, F. and Lalu, NM. (1996). Narrowing sex differentials in life expectancy in the industrialized world: Early 1970's to early 1990's. Social Biology, 43(1-2), pp. 20-37.

Tyczynski, JE., Bray, F., Aareleid, T., Dalmas, M., Kurtinaitis, J., Plesko, I., Pompe-Kirn, V., Stengrevics, A. and Parkin, DM. (2004). Lung cancer mortality patterns in selected Central, Eastern and Southern European countries. International Journal of Cancer, 109(4), pp. 598-610.

US Department of Health and Human Services (USDHSS), National Center for Chronic Disease Prevention and Health Promotion, Office on Smoking and Health (1989). A report of the surgeon general. Atlanta: Centers for Disease Control and Prevention.

US Department of Health and Human Services, National Center for Chronic Disease Prevention and Health Promotion, Office on Smoking and Health (2014). The health consequences of smoking - 50 years of progress: a report of the surgeons general. Atlanta: Centers for Disease Control and Prevention.

Utasi, Á. (2011). Szubjektív feszültség és munkastressz a házasok életében. Összehasonlítás Európa 24 országában. [Subjective tension and work stress in the life of married people. A comparison of 24 countries across Europe] In: I. Nagy and T. Pongrácz, eds., Szerepváltozások: Jelentés a nök és férfiak helyzetéröl [Changing Roles: Report on the Situation of Women and Men] Budapest: TÁRKI, Nemzeti Erőforrás Minisztérium, pp. 243-264. 
Vitrai, J., Bakacs, M., Balku, E., Bodrogi, J., Demjén, T., Joó, T., Vámos, M. and Vokó, Z. (2012). A dohányzás társadalmi terhei Magyarországon: kiemelt megállapítások. [The social burdens of smoking in Hungary: highlighted findings] Budapest: Országos Egészségfejlesztési Intézet (OEFI).

Vokó, Z. (2009). A dohányzás visszaszorítása, mint kiemelt népegészségügyi prioritás [The suppression of smoking as an outstanding priority of public health] Interdiszciplináris Magyar Egészségügy, 8(3), pp. 35-39.

Waldron, I. (1986). The contribution of smoking to sex differences in mortality. Public Health Reports, 101(2), pp. 163-173.

Waldron, I. (1991). Patterns and causes of gender differences in smoking. Social Science and Medicine, 32(9), pp. 989-1005.

Waldron, I. (1993). Recent trends in sex mortality ratios for adults in developed countries. Social Science and Medicine, 36(4), pp. 451-462.

Waldron, I. (2000). Trends in gender differences in mortality: Relationships to changing gender differences in behavior and other casual factors. In: E. Annandale and K. Hunt, eds., Gender inequalities in health. Buckingham, UK and Philadelphia: Open University Press, pp. 150-181.

Wéber, A. (2017). The impact of smoking on mortality in Hungary, 2000-2014. Hungarian Statistical Review, 95(K21), pp. 3-28.

\section{DATA SOURCES}

For the calculation of the smoking-attributable mortality in Hungary (see detailed method in Wéber 2017):

- Hungarian Central Statistical Office (HCSO) - Death Register, number of deaths by sex, age group, causes of death

- National Population Health Survey 2000 and 2003 (Országos lakossági egészségfelmérés) and European Health Interview Survey (EHIS) 2009, HCSO

For the year 2014 smoking prevalence in Hungary:

- European Health Interview Survey (EHIS) 2014, HCSO, prevalences and their 95\% confidence intervals by sex, age group, and smoking status 


\section{APPENDIX I (FOR FIGURES 1, 2, 3)}

$\begin{array}{lrc} & \text { Smoking prevalence } & \text { Smoking-attributable deaths } \\ \text { USA } & \text { Thun et al., } 2012 & \text { Thun et al., } 2012 \\ \text { Hungary } & \text { Tombor et al., 2010, } \\ \text { Böti et al., 2011, } & \text { EHIS, 2014 } \\ \text { Austria } & \text { Thompson et al., 2013 } & \text { Peto et al., } 2011 \\ & \text { WHO-HFA, 2014 }\end{array}$

Smoking prevalence is measured by:

Thun et al., 2012 - "Data on adult smoking prevalence from 1965 to 2010 represent measurements from the USA National Health Interview Survey. Projections through 2025 estimated based on current trends in early middle-age"

Tombor et al., 2010 - for the year 1984 and 1994 smoking prevalence in Hungary. Sources: Microcensus 1984, "Data collection on health status", 1994, $\mathrm{HCSO}$

Bőti et al., 2011 - for the year 2000, 2003 and 2009 smoking prevalence in Hungary. Sources: National Population Health Survey 2000 and 2003 (Országos lakossági egészségfelmérés) and European Health Interview Survey (EHIS) 2009, HCSO

EHIS, 2014 - for the year 2014 smoking prevalence in Hungary. Source: and European Health Interview Survey (EHIS) 2014, HCSO

Thompson et al., 2013 - for the year 1972, 1979, 1986, 1997 and 2006 smoking prevalence in Austria. Source: Table 1 - Prevalence of smoking (in percent) by sex and age group for selected survey years, age-specific prevalence values averaged

WHO-HFA, 2014 - for the year 2014 smoking prevalence in Austria. Source: WHO - Health for All Database: https://gateway.euro.who.int/en/indicators/ hfa_421-3010-of-regular-daily-smokers-in-the-population-age-15plus/

Smoking-attributable deaths are measured by:

Thun et al, 2012 - "Smoking-attributed deaths estimated indirectly from lung cancer rates and expressed as a percentage of all deaths" (Peto et al., 1992, 2011). 
APPENDIX II (FOR FIGURES 5, 6, 9, 10, 11)

To obtain the smoking-attributable age-specific probability of dying:

$$
a_{x s}=\left(5 * m_{x s}\right) /\left(1+\left(5-a_{x}\right) * m_{x s}\right)
$$

where $x$ refers to the specific age-groups, $m_{x s}$ is the smoking-attributable central death rate and $a_{x}$ is the parameter (from the Human Mortality Database: http://mortality.org) to estimate mid-term mortality. The formula is the same for the smoking-attributable causes of deaths, just calculated for every cause each. 